\title{
Effect of Interaction among N Forms and Calcium Sources on Quality and Chemical Composition of Tomato(Lycopersicon esculentum)
}

\author{
K.F. Fouda \\ Soil Sci. Dept., Fac. of Agric., Mansoura Univ., Egypt
}

\begin{abstract}
A FIELD experiment was conducted at the Experimental Farm of the Faculty of Agric. El-Mansoura Univ. During season of 2013 to evaluate the effect of $\mathrm{N}$-fertilization forms and different sources of calcium on chemical constitutes of tomato plant and its quality (Lycopersicon esculentum) "Carmen varaity".

Twelve treatments were arranged in split block design with 3 replicates, which were the simple possible combination between three forms of nitrogen fertilizers [ammonium sulfate, ammonium nitrate and urea] as main plots, and four sources of calcium (control, calcium chloride, calcium sulfate and calcium nitrate) as sub plots. Thus the total number of plots used for the season was 36 plots.

The results showed that; soil application of N-forms; ammonium sulfate, ammonium nitrate and urea significantly affected the average values of chlorophyll (a, b and total, mg.g-1), N, P, K and Ca\% in the leaves and tomato quality of fruits such as $\mathrm{N}, \mathrm{P}, \mathrm{K}$ andCa\%, V.C, total carbohydrates, lycobien, nitrate, acidity and TSS. Except for nitrate and acidity contentsthe highest mean valuewas recorded for the plants treated with ammonium sulfate,while such effect for nitrate and acidity contents were recorded for the treatments of ammonium nitrate and urea, respectivelyexcept for acidity values.
\end{abstract}

Also, the results, indicated that the mean values of all mentioned parameters were significantly increased with using different sources of calcium; calcium nitrate, calcium chloride and calcium sulfate comparing with the untreated plants, and the highest values were recorded with using calcium nitrate as a source of calcium.On the contrary of this trend, the average values of acidity were significantly decreased under any source of calcium addition and recorded the highest value for the untreated plants.

Generally, the most suitable treatment which realized the highest safe yield for tomato fruits was connected with the treatment of ammonium sulfate $+\mathrm{Ca} 2 \mathrm{NO} 3$.

Keywords: N-forms, Ca sources, Tomato plant,Quality.

\section{$\underline{\text { Introduction }}$}

Tomato (Lycopersiconesculentum Mill) (Family: Solanaceae) has become a major world food crop. Today, tomatoes are grown commercially in 159 countries. Tomatoes is one of the most important vegetables crops cultivated in Egypt, since, the Egyptian annual tomato consumption, was about 6.07 million ton a year, with average of $75.5 \mathrm{~kg} /$ person a year (MALR 2003-2005 and
Abd El-Ghany, 2011). According to FAOSTAT, in 2012, Egypt ranked as one of the top producers of tomatoes $(8,625,219 \mathrm{t}$ were produced). The cultivated area of tomato in Egypt increased considerably during the last two decades. In 2011, the total cultivated area, andproductivity of tomato in Egypt, was estimated by 505,823 feddan, yielding 805,3701 tons with an average of 15.92 tons/feddan (Anonymous, 2011). 
Nitrogen is an essential nutrient fertilizer for plant growth and development and is the world's largest agricultural chemical fertilizer. Plants can use various forms of nitrogen from soils, most importantly the inorganic ions ammonium (NH4+) and nitrate (NO3-). Nevertheless, urea constitutes another nitrogen source widely used by plants. In fact to provide crops production urea is intensively used as a nitrogen fertilizer. Urea nitrogen enters the plant either directly, or in the form of ammonium or nitrate after urea degradation (Byrnes and Freney, 1995). Urease is the enzyme responsible of urea hydrolysis producing ammonium (Guetteset et al., 2002). $\mathrm{NH} 4+-\mathrm{N}$ is one of the major nutrients for plants, and a ubiquitous intermediate in plant metabolism (Von Wirenet et al., 2000). Because NH4+-N assimilation requires less energy than that of NO3--N, it is usually expected to be preferred by plants (Brittoet et al., 2001). However, the ammonium ion is notorious for its toxic effects on many, if not all, plant strains: only a few strains perform well when NH4+ is the only, or predominant, nitrogen source (Kronzucker et al., 1997 and Li et al., 2009). In reality, ammonium is markedly present in agricultural soils as a result of fertilizers use, nitrogen cycle, or pollution. This additional NH4+-N input affected species composition: even local species extinction, and large-scale forest decline was attributed directly to the ammonium (Dai et al., 2008). Numerous studies demonstrated that different $\mathrm{N}$ forms significantly influenced plant growth, but contrasting results were observed depending on the plant species used.

Calcium is an important nutrient that plays a key role in the structure of cell walls and cell membranes, fruit growth, and development, as well as general fruit quality (Kadir, 2004). It enhances resistance to bacterial and viral diseases (Usten et al., 2006). The calcium taken up from the soil is trans located to the leaves but very little goes from the leaves to the fruit (Kadir,2004). Therefore, plants need a constant supply of calcium for vigorous leaf and root development and canopy growth (Del-Amor and Marcelis, 2003). However, the mechanisms that increase the resistance of plants to pathogen attacks related to the Ca-nutrition status of plants have not been fully elucidated. It has been postulated that high $\mathrm{Ca}$ levels in plant tissues lead to the formation of Ca-complexes with pectic substances that account for resistance of plants to fungal diseases. Snoeijerset al. (2000) reported that the nutritional status of the plant affects specifically transcription of in plantainduced genes of pathogens.

This study was conducted to determine the effect of different $\mathrm{N}$-forms on chemical and quality of tomato plants under different sources of $\mathrm{Ca}$ application.

\section{Materials and Methods}

A field experiment was conducted at the Experimental Farm of the Faculty of Agric. El-Mansoura Univ. during seasons of 2013 to evaluate the effect of $\mathrm{N}$-fertilization forms and different sources of calcium on chemical constitutes of tomato plant and its quality (Lycopersicon esculentum) "Carmen varaity"".

Some physical and chemical properties of the investigated soil layer of cultivated area ( 0.0 to $30 \mathrm{~cm}$ depth) are given in Table 1 .

Twelve treatments were arranged in split block design with 3 replicates, which were the simple possible combination between three forms of nitrogen fertilizers [ammonium sulfate(A.S), ammonium nitrate(A.N) and urea(U)] as main plots, and four sources of calcium (control, calcium chloride, calcium sulfate and calcium nitrate) as sub plots. Thus the total number of plots used for the season was 36 plots.

TABLE 1. Physical and chemical properties of the used soil during experiment.

\begin{tabular}{|c|c|c|c|c|c|c|c|c|c|c|c|c|}
\hline \multicolumn{13}{|c|}{ Soil properties } \\
\hline \multicolumn{5}{|c|}{ Particlesize distribution (\%) } & \multirow[b]{2}{*}{$\begin{array}{c}\text { E.C. } \\
\text { dS.m-1 } \\
(1: 5)\end{array}$} & \multirow[b]{2}{*}{$\underset{(1: 2.5)}{\text { pH }}$} & \multirow[b]{2}{*}{$\begin{array}{c}\text { S.P } \\
\%\end{array}$} & \multirow[b]{2}{*}{$\begin{array}{c}\text { O.M } \\
\%\end{array}$} & \multirow[b]{2}{*}{$\begin{array}{c}\text { T. } \\
\text { CaCO3 } \\
\% \\
\end{array}$} & \multicolumn{3}{|c|}{ Available (mg/kg) } \\
\hline $\begin{array}{c}\text { Coarse } \\
\text { sand }\end{array}$ & $\begin{array}{l}\text { Fine } \\
\text { sand }\end{array}$ & Silt & Clay & $\begin{array}{c}\text { Texture } \\
\text { class }\end{array}$ & & & & & & $\mathbf{N}$ & $\mathbf{P}$ & $\mathbf{K}$ \\
\hline 1.77 & 23.12 & 43.60 & 31.51 & $\begin{array}{l}\text { Sandy } \\
\text { clay } \\
\text { loam }\end{array}$ & 0.81 & 7.95 & 53 & 1.56 & 3.86 & 44.02 & 4.77 & 192 \\
\hline
\end{tabular}

Egypt. J. Soil Sci. 57 No. 2 (2017) 
The recommended chemical fertilizers for tomato production was used as follows: Nitrogen fertilizer 120 kg.fed-1was applied using ammonium nitrate $(33.5 \% \mathrm{~N})$, ammonium sulfate $(20.5 \% \mathrm{~N})$ and urea $(46 \% \mathrm{~N})$. Phosphor fertilizer was applied as super phosphate 60 kg.fed-1 (15\% P2O5). Potassium fertilizer was applied in potassium sulfate48 kg.fed-1 (48\% $\mathrm{K} 2 \mathrm{O}$ ). Treatments of $\mathrm{N}, \mathrm{P}$ and $\mathrm{K}$ fertilizers were divided into three equal doses and applied after 3, 7 and 10 weeks from transplanting.

Calcium sources were applied as foliar application at rate of $200 \mathrm{ppm}$. Plants were sprayed three times with the different assigned treatments starting after 21 days from transplanting and repeated after 7 days from the last one.

At mid-March during 2013 of the study, tomato seedling variety of Carmen weretransplanting into open field with space of $15 \times 4 \mathrm{~m}$ with total area $60 \mathrm{~m} 2$. Throughout the experiment, soil moisture was kept at field capacity.

30 days after transplanting of tomato seedlings; 3 plants were randomly taken from each treatment and carried immediately to the laboratory. Plant samples were oven dried at $700 \mathrm{c}$ tell constant weight was reached, The dried plant samples were thoroughly ground and stored for chemical analysis in leaves were $\mathrm{N}, \mathrm{P}$ and $\mathrm{K}$ and chlorophylls ( $\mathrm{a}, \mathrm{b}$ and total chlorophyll) were determined.

Representative samples of tomato fruits were randomly taken from each treatment after 120 days from transplanting when harvested starting to determine the quality parameters of tomato fruits and which expressed as follows; NO3-N (mg/kg), Vitamin C (mg/100g), Acidity \%, Lycobin, and T.S.S.\% as well as total cabohydrates\%. Random samples of tomato fruits were randomly chosen from each treatment, oven dried at $70^{\circ} \mathrm{C}$ and ground for the determination of $\mathrm{N}, \mathrm{P}$ and $\mathrm{K}$ contents.

\section{${ }^{a}$ Soil analysis}

The electrical conductivity values of the 1 : 5 soil paste extracts were measured by EC, $\mathrm{pH}$ value, $\mathrm{CaCo} 3$ and organic matter contents were determined according to Sahlemedhin and Taye (2000).
Particle size distribution, available N,P and $\mathrm{K}$ in the soil were determined according to the methods of Haluschak (2006) and Reeuwijk(2002).

\section{${ }^{a}$ Chemical composition and quality fruits}

Total N, P and K (\%) was determined according to the methods described by Mertens (2005a\& b) and Agrilasa (2002), respectively.

Chlorophyll content was estimated as the method described by Gavrilenko and Zigalova (2003).

NO3-N (mg/kg), Vitamin C (mg/100g), Acidity \%, Lycobin, and T.S.S.\% as well as total cabohydrates $\%$ were determined according to Singh (1988), (A.O.A.C.; 2006), Wu (2002), and Ranganna (2001), respectively.

All data were statistically analyzed according to the technique of analysis variance (ANOVA) and the least significant difference (L.S.D) method was used to compare the deference between the means of treatment values to the methods described by Gomez and Gomez,(1984). All statistical analyses were performed using analysis of variance technique by means of CoSTATE Computer Software.

\section{$\underline{\text { Results }}$}

Chlorophyll content in leaves and total yield

As shown in Table 2 it could be observed that; a stimulation effect was happened on the mean values of the chlorophyll $(a, b$, total chlorophyll) and total yield due to an application of the studied forms of nitrogen fertilization as ammonium nitrate, ammonium sulfate and urea. Such effect was more pronounced for the plants fertilized with ammonium sulfate, which recorded the highest values of chlorophyll (a, b \&a+b) and total yield in the season of the experimentation as compared to the other $\mathrm{N}$ fertilization forms investigated.

Regarding the effect of foliar application of different sources of $\mathrm{Ca}$, data in Table 2 revealed that foliar application of $\mathrm{Ca}$ significantly increased the mean values of chlorophyll $(a, b$ $\& \mathrm{a}+\mathrm{b} \mathrm{mg}$ g-1) in tomato leaves and total yield as compared with the untreated plants. On other words; the highest values recorded were $(0.706,0.4991 .205$ for chlorophyll $(a, b$, total 
chlorophyll) and 31.98 ton.fed-1 for total yield, respectively were realized for the plants treated with calcium nitrate at the rate of $200 \mathrm{ppm}$ compared with the other treatments.

The different comparison between the mean values of chlorophyll $(\mathrm{a}, \mathrm{b} \& \mathrm{a}+\mathrm{b})$ and total yield as affected by the combination between different sources of $\mathrm{Ca}$ and $\mathrm{N}$ forms under investigation are presented in Table 2. Data clearly showed that; a stimulation effect on the average values of chlorophyll $(\mathrm{a}, \mathrm{b} \& \mathrm{a}+\mathrm{b})$ in tomato leaves and total yield due to an addition of calcium sources as foliar spraying under any forms of $\mathrm{N}$-fertilization as soil application as compared to the untreated plants. it can be observed that the most suitable treatment, which achieved the highest mean values of chlorophyll and yield of tomato plant was connected with the plants treated with calcium nitrate and ammonium sulphat while the lowest one was associated with the treatment of the untreated plants.

\section{$N, P, K$ and $C a \%$ in leaves}

Table 3 indicated that; the average values of all nutritional elements in tomato plant were significantly affected as a result of treating tomato plant with the $\mathrm{N}$-forms investigated. The highest mean values for the $\mathrm{N}, \mathrm{P}, \mathrm{K}$ and $\mathrm{Ca} \%$ in leaves were found to be associated with the addition of ammonium sulfate, while the lowest values was recorded for the plants treated with urea.

According to the data illustrated in the same table it is evident that foliarly applied of different sources of calcium on tomato plant at the rate of $200 \mathrm{ppm}$ significantly increased the mean values of $\mathrm{N}, \mathrm{P}, \mathrm{K}$ and $\mathrm{Ca} \%$ in tomato leaves. Comparing with the control treatment rate of increases for $\mathrm{N}, \mathrm{P}, \mathrm{K}$, and Carespectively were accounted to

TABLE 2. Effect of different nitrogen forms and calcium sources on chlorophyll content

\begin{tabular}{|c|c|c|c|c|c|}
\hline \multicolumn{2}{|c|}{$\begin{array}{l}\text { Char. } \\
\text { Treat. }\end{array}$} & $\begin{array}{c}\text { Chlor. a. mg/g } \\
\text { F.W }\end{array}$ & $\begin{array}{c}\text { Chlor. b. mg/g } \\
\text { F.W }\end{array}$ & $\begin{array}{c}\text { Chlor. a + b mg/g } \\
\text { F.W }\end{array}$ & $\begin{array}{c}\text { Total yield ton. } \\
\text { fed-1 }\end{array}$ \\
\hline \multicolumn{6}{|c|}{ Nitrogen forms } \\
\hline \multicolumn{2}{|c|}{ A.N } & 0.674 & 0.474 & 1.148 & 28.75 \\
\hline \multicolumn{2}{|c|}{ A.S } & 0.685 & 0.482 & 1.167 & 29.81 \\
\hline \multicolumn{2}{|c|}{$\mathrm{U}$} & 0.671 & 0.471 & 1.142 & 28.28 \\
\hline \multicolumn{2}{|c|}{ LSD at $5 \%$} & 0.006 & 0.009 & 0.010 & 0.39 \\
\hline \multicolumn{6}{|c|}{ Calcium sources } \\
\hline \multicolumn{2}{|c|}{ Without $\mathrm{Ca}$} & 0.637 & 0.446 & 1.083 & 24.79 \\
\hline \multicolumn{2}{|c|}{$\mathrm{Ca}(\mathrm{NO} 3) 2$} & 0.706 & 0.499 & 1.205 & 31.98 \\
\hline \multicolumn{2}{|c|}{$\mathrm{CaSO} 4$} & 0.698 & 0.491 & 1.189 & 31.22 \\
\hline \multicolumn{2}{|c|}{$\mathrm{CaCl} 2$} & 0.666 & 0.466 & 1.132 & 27.80 \\
\hline \multicolumn{2}{|c|}{ LSD at $5 \%$} & 0.009 & 0.004 & 0.010 & 0.54 \\
\hline \multicolumn{6}{|c|}{ Interaction } \\
\hline \multirow{4}{*}{ A.N } & Without Ca & 0.630 & 0.439 & 1.069 & 23.93 \\
\hline & $\mathrm{Ca}(\mathrm{NO} 3) 2$ & 0.689 & 0.485 & 1.174 & 30.28 \\
\hline & $\mathrm{Ca} \mathrm{SO} 4$ & 0.715 & 0.505 & 1.220 & 32.93 \\
\hline & $\mathrm{CaCl} 2$ & 0.661 & 0.468 & 1.129 & 27.87 \\
\hline \multirow{4}{*}{ A.S } & Without $\mathrm{Ca}$ & 0.646 & 0.453 & 1.100 & 25.66 \\
\hline & $\mathrm{Ca}(\mathrm{NO} 3) 2$ & 0.724 & 0.514 & 1.238 & 33.71 \\
\hline & $\mathrm{CaSO} 4$ & 0.699 & 0.489 & 1.188 & 31.20 \\
\hline & $\mathrm{CaCl} 2$ & 0.672 & 0.471 & 1.143 & 28.68 \\
\hline \multirow{4}{*}{$\mathrm{U}$} & Without $\mathrm{Ca}$ & 0.634 & 0.447 & 1.081 & 24.78 \\
\hline & $\mathrm{Ca}(\mathrm{NO} 3) 2$ & 0.706 & 0.497 & 1.204 & 31.94 \\
\hline & $\mathrm{CaSO} 4$ & 0.680 & 0.479 & 1.159 & 29.53 \\
\hline & $\mathrm{CaCl} 2$ & 0.665 & 0.459 & 1.124 & 26.85 \\
\hline & & 0.016 & 0.007 & 0.017 & 0.94 \\
\hline
\end{tabular}

Egypt. J. Soil Sci. 57 No. 2 (2017) 
TABLE 3. Effect of different nitrogen forms and calcium sources on $N, P, K$ and $C a \%$ in leaves

\begin{tabular}{|c|c|c|c|c|c|}
\hline \multicolumn{2}{|c|}{$\begin{array}{l}\text { Char. } \\
\text { Treat. }\end{array}$} & $\mathrm{N} \%$ & P \% & K \% & $\mathrm{Ca} \%$ \\
\hline \multicolumn{6}{|c|}{ Nitrogen forms } \\
\hline \multicolumn{2}{|l|}{ A.N } & 2.82 & 0.348 & 2.45 & 2.58 \\
\hline \multicolumn{2}{|l|}{ A.S } & 2.93 & 0.356 & 2.56 & 2.68 \\
\hline \multicolumn{2}{|l|}{$\mathrm{U}$} & 2.78 & 0.341 & 2.41 & 2.51 \\
\hline \multicolumn{2}{|l|}{ LSD at $5 \%$} & 0.03 & 0.006 & 0.02 & 0.04 \\
\hline \multicolumn{6}{|c|}{ Calcium sources } \\
\hline \multicolumn{2}{|l|}{ Without $\mathrm{Ca}$} & 2.43 & 0.311 & 2.09 & 2.17 \\
\hline \multicolumn{2}{|l|}{$\mathrm{Ca}(\mathrm{NO} 3) 2$} & 3.14 & 0.376 & 2.79 & 2.91 \\
\hline \multicolumn{2}{|l|}{$\mathrm{Ca} \mathrm{SO} 4$} & 3.07 & 0.370 & 2.69 & 2.81 \\
\hline \multicolumn{2}{|l|}{$\mathrm{CaCl} 2$} & 2.73 & 0.336 & 2.32 & 2.46 \\
\hline \multicolumn{2}{|l|}{ LSD at $5 \%$} & 0.04 & 0.005 & 0.03 & 0.03 \\
\hline \multicolumn{6}{|c|}{ Interaction } \\
\hline \multirow{4}{*}{ A.N } & Without $\mathrm{Ca}$ & 2.35 & 0.302 & 1.99 & 2.10 \\
\hline & $\mathrm{Ca}(\mathrm{NO} 3) 2$ & 2.97 & 0.362 & 2.63 & 2.74 \\
\hline & $\mathrm{Ca} \mathrm{SO} 4$ & 3.23 & 0.388 & 2.87 & 2.99 \\
\hline & $\mathrm{CaCl} 2$ & 2.74 & 0.339 & 2.33 & 2.47 \\
\hline \multirow{4}{*}{ A.S } & Without $\mathrm{Ca}$ & 2.52 & 0.318 & 2.18 & 2.27 \\
\hline & $\mathrm{Ca}(\mathrm{NO} 3) 2$ & 3.31 & 0.394 & 2.97 & 3.08 \\
\hline & $\mathrm{Ca} \mathrm{SO} 4$ & 3.06 & 0.369 & 2.68 & 2.83 \\
\hline & $\mathrm{CaCl} 2$ & 2.82 & 0.342 & 2.41 & 2.54 \\
\hline \multirow{4}{*}{$\mathrm{U}$} & Without $\mathrm{Ca}$ & 2.43 & 0.312 & 2.10 & 2.12 \\
\hline & $\mathrm{Ca}(\mathrm{NO} 3) 2$ & 3.14 & 0.371 & 2.78 & 2.92 \\
\hline & $\mathrm{Ca} \mathrm{SO} 4$ & 2.90 & 0.353 & 2.53 & 2.63 \\
\hline & $\mathrm{CaCl} 2$ & 2.64 & 0.326 & 2.23 & 2.36 \\
\hline \multicolumn{2}{|l|}{ LSD at $5 \%$} & 0.07 & 0.009 & 0.06 & 0.06 \\
\hline
\end{tabular}

be $29.22,20.90,33.49 \& 34.10 \%$ for the form of calcium nitrate. On the contrary of this trend, other additions of different sources significantly decreased the mean values of $\mathrm{N}, \mathrm{P}, \mathrm{K}$ and $\mathrm{Ca} \%$ in tomato leaves more than those obtained for the untreated plants.

Nutritional elements concentrations in tomato plant as affected by the interaction between all treatments under study are tabulated in Table 3. Data revealed that, it can be observed that within the $\mathrm{N}$-forms under study a supority effect was recorded on the mean values of $\mathrm{N}, \mathrm{P}, \mathrm{K}$ and $\mathrm{Ca} \%$ of tomato leaves for the treatment of ammonium sulfate as compared to ammonium nitrate or urea and such effect was more pounced for the plants treated with different sources of calcium than those obtained from the untreated plants. In addition, foliarly applied calcium in forms of calcium nitrate combined with any forms of $\mathrm{N}$-fertilization significantly increased the average values of $\mathrm{N}, \mathrm{P}, \mathrm{K}$ and $\mathrm{Ca} \%$ in tomato leaves. Thus, the most suitable treatment, which realized the highest mean values of N, P, K and Cawas connected with the plants treated with ammonium sulfate and calcium nitrate, while the lowest values was obtained from the untreated plants.

\section{$N, P, K$ and $C a \%$ in fruits}

Data of Table 4 illustrated that; using different forms of nitrogen fertilization as ammonium nitrate, ammonium sulfate and urea significantly affected the $\mathrm{N}, \mathrm{P}, \mathrm{K}$ and $\mathrm{Ca} \%$ of tomato fruits, within the $\mathrm{N}$-forms investigation the highest mean values of all mentioned nutrients recorded with adding of ammonium sulfate following with ammonium nitrate and lately urea. 
Data in Table 4 showed that; the average values of $\mathrm{N}, \mathrm{P}, \mathrm{K}$ and $\mathrm{Ca} \%$ of tomato fruits studied treated with 200 ppm Ca were increased comparing with the control treatment (tap water). The rate of increase over the control treatment were $29.11,28.87,45.86 \& 31.30 \%$ for $\mathrm{N}, \mathrm{P}, \mathrm{K}$ and $\mathrm{Ca} \%$ of tomato fruits, respectively at the form of calcium nitrate. The differences between these values were significant for all mentioned nutrient of tomatoes under other treatments during the season of the experiment.

The interaction effect among the treatments under study are presented in Table 4 . It could be observed that; the average values of all nutrient studied were significantly affected due to the addition of all investigated treatments. Such effect was more pronounced for the treatment of sprayed $200 \mathrm{mg} \mathrm{L}-1$ Calcium nitrate with all forms of nitrogen studied. In this connect, the highest mean values during the experiment were2.92, 0.381, 2.47and 3.64 for $\mathrm{N}, \mathrm{P}, \mathrm{K}$ and $\mathrm{Ca} \%$ of tomato fruits, respectively were recorded for the plants treated with the $200 \mathrm{ppm}$ Calcium nitrate with using ammonium sulfate as $\mathrm{N}$-forms.

\section{V.C, T.carbohydrates and lycobin}

Data of Table 5 reflected that; a higher amount of V.C, T.carbohydrates and lycobin of tomato fruits due to an addition of ammonium sulfate at the rate of $250 \mathrm{Kg}$ fed- 1 for tomato plants more than those obtained from the plants treated with other forms of nitrogen fertilization; ammonium nitrate and urea at the same rate. In this connect; the highest mean values were 16.16, 39.02\&10.26, respectively for V.C, T.carbohydrates and lycobin of tomato fruits was conducted with the treatment of A.S, while the lowest values recorded with adding urea.

TABLE 4. Effect of different nitrogen forms and calcium sources on $\mathrm{N}, \mathrm{P}, \mathrm{K}$ and $\mathrm{Ca} \%$ in tomato fruits

\begin{tabular}{|c|c|c|c|c|c|}
\hline \multicolumn{2}{|c|}{ Char. Treat. } & N \% & P \% & K \% & $\mathrm{Ca} \%$ \\
\hline \multicolumn{6}{|c|}{ Nitrogen forms } \\
\hline \multicolumn{2}{|l|}{ A.N } & 2.45 & 0.328 & 1.96 & 3.05 \\
\hline \multicolumn{2}{|l|}{ A.S } & 2.55 & 0.338 & 2.07 & 3.20 \\
\hline \multicolumn{2}{|l|}{ U } & 2.44 & 0.333 & 1.90 & 3.01 \\
\hline \multicolumn{2}{|l|}{ LSD at $5 \%$} & 0.04 & 0.019 & 0.04 & 0.04 \\
\hline \multicolumn{6}{|c|}{ Calcium sources } \\
\hline \multicolumn{2}{|l|}{ Without Ca } & 2.13 & 0.284 & 1.57 & 2.62 \\
\hline \multicolumn{2}{|l|}{$\mathrm{Ca}(\mathrm{NO} 3) 2$} & 2.75 & 0.366 & 2.29 & 3.44 \\
\hline \multicolumn{2}{|l|}{$\mathrm{Ca} \mathrm{SO} 4$} & 2.69 & 0.356 & 2.20 & 3.35 \\
\hline \multicolumn{2}{|l|}{$\mathrm{CaCl} 2$} & 2.35 & 0.324 & 1.84 & 2.94 \\
\hline \multicolumn{2}{|l|}{ LSD at $5 \%$} & 0.03 & 0.015 & 0.04 & 0.04 \\
\hline \multicolumn{6}{|c|}{ Interaction } \\
\hline \multirow{4}{*}{ A.N } & Without $\mathrm{Ca}$ & 2.02 & 0.276 & 1.50 & 2.50 \\
\hline & $\mathrm{Ca}(\mathrm{NO} 3) 2$ & 2.58 & 0.349 & 2.11 & 3.26 \\
\hline & $\mathrm{Ca} \mathrm{SO} 4$ & 2.86 & 0.374 & 2.36 & 3.52 \\
\hline & $\mathrm{CaCl} 2$ & 2.35 & 0.312 & 1.86 & 2.94 \\
\hline \multirow{4}{*}{ A.S } & Without $\mathrm{Ca}$ & 2.18 & 0.292 & 1.67 & 2.74 \\
\hline & $\mathrm{Ca}(\mathrm{NO} 3) 2$ & 2.92 & 0.381 & 2.47 & 3.64 \\
\hline & $\mathrm{Ca} \mathrm{SO} 4$ & 2.68 & 0.356 & 2.22 & 3.39 \\
\hline & $\mathrm{CaCl} 2$ & 2.42 & 0.323 & 1.92 & 3.05 \\
\hline \multirow{4}{*}{ U } & Without $\mathrm{Ca}$ & 2.18 & 0.285 & 1.54 & 2.63 \\
\hline & $\mathrm{Ca}(\mathrm{NO} 3) 2$ & 2.76 & 0.368 & 2.29 & 3.41 \\
\hline & $\mathrm{Ca} \mathrm{SO} 4$ & 2.52 & 0.339 & 2.02 & 3.15 \\
\hline & $\mathrm{CaCl} 2$ & 2.27 & 0.339 & 1.75 & 2.84 \\
\hline \multicolumn{2}{|l|}{ LSD at $5 \%$} & 0.06 & 0.027 & 0.06 & 0.07 \\
\hline
\end{tabular}


Such effect of the foliar application of different sources of $\mathrm{Ca}$ on the mean values of V.C, T.carbohydrates and lycobin of tomato fruits are presented in Table 5. Data showed that treating tomato plant with $\mathrm{Ca}$ at $200 \mathrm{ppm}$ significantly increased the average values of the previously mentioned traits than those obtained for the untreated treatment. Comparing with the control treatment, the rate of increase on the contents of V.C were (16.68, 13.93 and $5.15 \%$, respectively), T.carbohydrates were $(4.49,3.94 \& 1.64 \%)$ and licobin were $(17.36,15.28 \& 6.44 \%)$ for the treatments of $200 \mathrm{ppm} \mathrm{Ca}(\mathrm{NO} 3) 2, \mathrm{Ca} \mathrm{SO} 4$ and $\mathrm{CaCl} 2$, respectively during the experiment.

Data in Table 5 reveal the effect of interactions between the previous treatments under study on the average values V.C, T.carbohydrates and lycobin of tomato fruits. It can be observed that; a considerable significant effect for the mean values of all the mentioned traits in tomato fruits under all treatments of the investigation. It can be recorded that; adding of $200 \mathrm{ppm}$ calcium nitrate in foliar way and $250 \mathrm{Kg}$ ammonium sulfate as soil addition maximizing the rules of V.C, T.carbohydrates and lycobin of tomato fruits.

\section{Nitrate, acidity and TSS}

With respect to the effect of $\mathrm{N}$-forms in Table 6 it is evident that; the highest mean values of nitrate accumulation was recorded for ammonium nitrate, and TSS recorded with ammonium sulfatewhile acidity recorded for the plants treated with $\mathrm{N}$-fertilization in the form of urea, while the lowest values of such traits were realized for the treatment of ammonium sulfate on tomato fruits.

Obtained data in Table 6 indicated that, the average values of nitrate accumulation and TSS

TABLE 5. Effect of different nitrogen forms and calcium sources on V.C, total carbohydrates and lycobin in tomato fruit

\begin{tabular}{|c|c|c|c|c|}
\hline \multicolumn{2}{|c|}{ Char. Treat. } & V.C mg/100g & T.carbohydrates \% & Licobin $\mathrm{mg} / \mathbf{1 0 0 g}$ \\
\hline \multicolumn{5}{|c|}{ Nitrogen forms } \\
\hline \multicolumn{2}{|l|}{ A.N } & 15.92 & 38.74 & 10.01 \\
\hline \multicolumn{2}{|l|}{ A.S } & 16.16 & 39.02 & 10.26 \\
\hline \multicolumn{2}{|l|}{$\mathrm{U}$} & 15.53 & 38.62 & 9.90 \\
\hline \multicolumn{2}{|l|}{ LSD at $5 \%$} & 0.12 & 0.08 & 0.07 \\
\hline & & Calcium source & & \\
\hline \multicolumn{2}{|l|}{ Without Ca } & 14.57 & 37.83 & 9.16 \\
\hline \multicolumn{2}{|l|}{$\mathrm{Ca}(\mathrm{NO} 3) 2$} & 17.00 & 39.55 & 10.75 \\
\hline \multicolumn{2}{|l|}{$\mathrm{Ca} \mathrm{SO} 4$} & 16.60 & 39.34 & 10.56 \\
\hline \multicolumn{2}{|l|}{$\mathrm{CaCl} 2$} & 15.32 & 38.47 & 9.75 \\
\hline \multicolumn{2}{|l|}{ LSD at $5 \%$} & 0.07 & 0.07 & 0.05 \\
\hline \multicolumn{5}{|c|}{ Interaction } \\
\hline \multirow{4}{*}{ A.N } & Without $\mathrm{Ca}$ & 14.89 & 37.61 & 8.99 \\
\hline & $\mathrm{Ca}(\mathrm{NO} 3) 2$ & 16.27 & 39.17 & 10.36 \\
\hline & $\mathrm{CaSO} 4$ & 17.21 & 39.73 & 10.98 \\
\hline & $\mathrm{CaCl} 2$ & 15.33 & 38.46 & 9.73 \\
\hline \multirow{4}{*}{ A.S } & Without $\mathrm{Ca}$ & 14.58 & 38.04 & 9.36 \\
\hline & $\mathrm{Ca}(\mathrm{NO} 3) 2$ & 17.75 & 39.96 & 11.15 \\
\hline & $\mathrm{Ca} \mathrm{SO} 4$ & 16.64 & 39.38 & 10.54 \\
\hline & $\mathrm{CaCl} 2$ & 15.66 & 38.71 & 9.96 \\
\hline \multirow{4}{*}{ U } & Without $\mathrm{Ca}$ & 14.24 & 37.82 & 9.14 \\
\hline & $\mathrm{Ca}(\mathrm{NO} 3) 2$ & 16.97 & 39.52 & 10.74 \\
\hline & $\mathrm{CaSO} 4$ & 15.96 & 38.90 & 10.15 \\
\hline & $\mathrm{CaCl} 2$ & 14.96 & 38.25 & 9.57 \\
\hline \multicolumn{2}{|l|}{ LSD at $5 \%$} & 0.12 & 0.12 & 0.09 \\
\hline
\end{tabular}


in tomato fruits were significantly increased over control due to addition of calcium in form of calcium nitrate in foliar way as compared to the untreated plants, while the acidity was significantly decreased for the plants treated with any forms of Caless than the control treatment (tap water) which recorded 24.21, 20.00 and $6.32 \%$ for $\mathrm{Ca}(\mathrm{NO} 3) 2, \mathrm{Ca} \mathrm{SO} 4$ and $\mathrm{CaCl} 2$ respectively, which mean that the highest values recorded with $\mathrm{CaCl} 2$ in foliar way.

Statistical analysis of the data in Table 6 revealed the average values of NO3-N, acidity and TSS as affected by the combination between the various treatments under investigation. It could be observed that; a positive effect was happened on the mean values of all quality parameters mentioned due to using the combination between the studied parameters. In this respect, the highest values; (69.80 for NO3-N ) and (5.72 for TSS) were obtained for the treatment of ammonium nitrate and sulfate, respectively as solely addition, under calcium nitrate while the highest values of acidity was recorded for the treatment of $200 \mathrm{ppm}$ $\mathrm{CaCl} 2+$ urea.

\section{Discussion}

For all the investigated parameters; a stimulation effect happened for the tomato plants treated with calcium by foliar way at rate of 200 $\mathrm{ppm}$ in forms of calcium nitrate as compared to the other treatments and untreated plants. Except the acidity decreased obviously in response to calcium addition at any form. This trend may be related to the many physiological roles played by calcium, such as signal transduction and its involving in the maintenance of cell wall and plasma membrane structural. Also, it plays a role in activating antioxidant enzymes and enhancing the endurance of nutrient stress. These responses

TABLE 6. Effect of different nitrogen forms and calcium sources on NO3-N, acidity and TSS in tomato fruit

\begin{tabular}{|c|c|c|c|c|}
\hline $\begin{array}{l}\text { Char. } \\
\text { Treat. }\end{array}$ & & NO3--N ppm & Acidity \% & TSS \% \\
\hline \multicolumn{5}{|c|}{ Nitrogen forms } \\
\hline \multicolumn{2}{|l|}{ A.N } & 63.47 & 0.83 & 5.38 \\
\hline \multicolumn{2}{|l|}{ A.S } & 60.75 & 0.81 & 5.46 \\
\hline \multicolumn{2}{|l|}{$\mathrm{U}$} & 62.06 & 0.86 & 5.36 \\
\hline \multicolumn{2}{|l|}{ LSD at $5 \%$} & 0.73 & 0.03 & 0.03 \\
\hline \multicolumn{5}{|c|}{ Calcium sources } \\
\hline \multicolumn{2}{|l|}{ Without Ca } & 60.01 & 0.95 & 5.15 \\
\hline \multicolumn{2}{|l|}{$\mathrm{Ca}(\mathrm{NO} 3) 2$} & 68.31 & 0.72 & 5.64 \\
\hline \multicolumn{2}{|l|}{$\mathrm{Ca} \mathrm{SO} 4$} & 55.90 & 0.76 & 5.47 \\
\hline \multicolumn{2}{|l|}{$\mathrm{CaCl} 2$} & 64.15 & 0.89 & 5.33 \\
\hline \multicolumn{2}{|l|}{ LSD at $5 \%$} & 0.52 & 0.03 & 0.03 \\
\hline \multicolumn{5}{|c|}{ Interaction } \\
\hline \multirow{4}{*}{ A.N } & Without $\mathrm{Ca}$ & 61.33 & 0.97 & 5.08 \\
\hline & $\mathrm{Ca}(\mathrm{NO} 3) 2$ & 69.80 & 0.82 & 5.64 \\
\hline & $\mathrm{Ca} \mathrm{SO} 4$ & 57.23 & 0.66 & 5.47 \\
\hline & $\mathrm{CaCl} 2$ & 65.53 & 0.89 & 5.31 \\
\hline \multirow{4}{*}{ A.S } & Without $\mathrm{Ca}$ & 58.73 & 0.93 & 5.22 \\
\hline & $\mathrm{Ca}(\mathrm{NO} 3) 2$ & 66.90 & 0.62 & 5.72 \\
\hline & $\mathrm{Ca} \mathrm{SO} 4$ & 54.53 & 0.79 & 5.49 \\
\hline & $\mathrm{CaCl} 2$ & 62.83 & 0.89 & 5.39 \\
\hline \multirow{4}{*}{$\mathrm{U}$} & Without $\mathrm{Ca}$ & 59.97 & 0.96 & 5.16 \\
\hline & $\mathrm{Ca}(\mathrm{NO} 3) 2$ & 68.23 & 0.72 & 5.56 \\
\hline & $\mathrm{Ca} \mathrm{SO} 4$ & 55.93 & 0.83 & 5.46 \\
\hline & $\mathrm{CaCl} 2$ & 64.10 & 0.91 & 5.28 \\
\hline \multicolumn{2}{|l|}{ LSD at $5 \%$} & 0.90 & 0.05 & 0.06 \\
\hline
\end{tabular}

Egypt. J. Soil Sci. 57 No. 2 (2017) 
are similar to those obtained by Eraslan et al. (2007) resulted that $\mathrm{Ca}$ concentrations in tomato fruits increased significantly with foliar-applied $\mathrm{Ca}$, with the exception of CaNO3.

Within the forms of $\mathrm{N}$-fertilizers; ammonium sulfate, ammonium nitrate and urea; the use of ammonium sulfate was most effective than the other forms of urea or ammonium nitrate. The superiorly effect of ammonium sulfate may be attributed to the role played by this acidic component which minimized the values of soil $\mathrm{pH}$ and, subsequently facilitate the absorption of nutrients by the roots of tomato plant. Such results was also observed by Ezzat et al. (2011) resulted that using ammonium sulfateled to significant increases in N, P, K uptake and quality of potato except NO3- and NO2-accumulation, which was significantly decreased in potato tubers, ammonium nitrate gave the highest residual NO3-N compared with other treatments of ammonium sulfate or urea. Such effect was found with Hozhabryan and Kazemi (2014 a \& b).

Ammonium sulfate resulted in increased levels of vitamin $\mathrm{C}$ and this confirms that the problem of ammonium sulfate fertilizer to increase the level of vitamin $\mathrm{C}$ in the tomato plant are effective. This is the result obtained by Heravi et al. (2005).

Forms of ammonium sulfate at rate of 250 kg.fed-1 in the chlorophyll index, this indicates that the ammonium form of nitrogen fertilizer on tomato plant growth and GREENS are effective in increasing levels of ammonium sulfate chlorophyll increases. The results obtained by the pyvast et al. (2007).

\section{Conclusion}

Under the same condition of this investigation it can be concluded that; soil addition of ammonium sulfate as a source of $\mathrm{N}$-fertilization in the presence of calcium nitrate as source of calcium at rate of $200 \mathrm{ppm}$ applied in foliar way is considered to be the most suitable treatment for realizing the highest safe yield quality of tomato plant.

\section{References}

Abd El-Ghany, N. M. (2011) Molecular evaluation of Bacillusthuringiensisisolates from the soil and production of transgenic tomato plants harboring
Btgene for controlling lepidopterous insects in Egypt. Ph.D. thesis, Faculty of Science, Ain Shams University, Cairo, Egypt, 270 pp.

Agrilasa (2002) Handbook on feeds and plant analyses. AGRILASA, Pretoria. SouthAfrica.

Anonymous (2011) Agricultural Statistics Bulletin. Central Administration of Economic. Ministry of Agriculture, Egypt, 184 pp.

AOAC (2006) Official Methods of Analysis, Ascorbic Acid in Vitamin Preparation and Juices.2, 6Dichloroindophenol Titrimetric Method. Vitamins and Other Nutrients Chapter 45, p. 19.

Britto, D.T. and Kronzucker, H.J. (2001) Constancy of nitrogen turn:-over kinetics in the plant cell: Insights into the integration of subcellular $\mathrm{N}$ fluxes. Planta, 213, 175-181.

Brynes, B. H. and Freney, J. R. (1995) Recent developments in the use of urease inhibitors in the tropics. Fertilizer Res., 42, 251-259.

Dai, G., Deblois, C. P., Liu,S., Juneau, P. and Qiu, B. (2008) Differential sensitivity of five cyanobacterial strains to ammonium toxicity and its inhibitory mechanism on the photosynthesis of rice-field cyanobacteriumGe-Xian-Mi(Nostoc). Aquatic Toxicology, 89, 113-121.

Del-Amor, F. K. and Marcelis, L. E. M. (2003) Regulation of nutrient uptake, water uptake and growth under calcium starvation and recovery. $J$. Hort. Sci. Biotechnol., 78,343-349.

Eraslan, F., Akbas, B., Inal1, A. and Tarakcioglu, C. (2007) Effects of Foliar Sprayed Calcium Sources on Tomatomosaic virus (ToMV) Infection in Tomato Plants Grown in Greenhouses. Phytoparasitica, 35 (2), 150-158.

Ezzat, A. S., Abd El-Hameed,A. M., Ahmed, H. M. I. and A. A. El-Awady (2011) Improving Nitrogen Utilization Efficiency by Potato (Solanumtuberosum L.). A. Influence of Nitrification Inhibitors in Combination with Different Nitrogen Sources on Reducing Nitrogen Losses, Improving Productivity and Chemical Composition. Nature and Sci. 9 (7), 26-33.

Gavrilenko V. F. and Zigalova,T. V. (2003) The Laboratory Manual for the Photosynthesis.

Egypt. J. Soil Sci. 57 No. 2 (2017) 
Academia, Moscow.256 стр. (in Russian).

Gomez, K. A. and Gomez,A. A. (1984) "Statistical Procedures for Agricultural Research”. John Wiley and Sons, Inc., New York.pp:680.

Guettes, R., Dott,W. and Esentraeger,A. (2002) Determination of urease activity in soils by carbon dioxide releas for ecotoxicological evaluation of contaminated soils. Ecotoxicology, 11, 357-346.

Haluschak, P. (2006) Laboratory Methods of Soil Analysis.Canada-Manitoba Soil Survey. April

Heravi, R., Bablar,M. , Kashki, I., Myrbdalbaqy,C. E. and Asgari, M. (2005) Effect ofChndmhlvl Webster's food culture in hydroponic greenhouse tomato varieties Hmra' on qualitative and quantitative characteristics. Iranian Agricultural Sciences, 0.946 to 939 .

Hozhabryan, M. and Kazemi, S. (2014 a) Effects of ammonium sulfate and urea fertilizers on the growth and yield of tomato. J. Nov. Appl Sci., 3 (2), 148-150

Hozhabryan, M. and Kazemi, S. (2014 b) Effects of ammonium sulfate on the growth and yield of different tomato((Lecopersiconesculentum) plant in the city jahrom. J. Nov. Appl Sci., 3 (1): 62-66.

Kadir, S. A. (2004) Fruit quality at harvest of 'Jonathan' apple treated with foliar applied calcium chloride. J. Plant Nut., 27, 1991-2006.

Kronzucker, H. J., Siddiqi, M. Y. and Glass, A. D. M. (1997) Conifer root discrimination against soil nitrate and the ecology of forest succession. Nature, $\mathbf{3 8 5}, 59-61$.

Mertens, D. (2005a) AOAC official method 922.02. plants preparation of laboratuary sample. Official Methods of Analysis, 18th ed. North Frederick Avenue, Gaitherburg, Maryland,1-2pp.

Mertens, D. (2005b) AOAC Official method 975.03. Metal in plants and pet foods.Official Methods of Analysis, 18th ed. North Frederick Avenue, Gaitherburg, Maryland, 3-4 pp.

Ministry of Agricultural and Land Reclamation (MALR) (2003-2005) Economic affairs sector, Agricultural Statistics Book.
Pyvast, G. (2007) In 1988.Effect of vermicompost and nitrogen fertilizer on growth, yield and quality traits and nitrate concentration in spinach.Congress of Horticultural Sciences, Shiraz, Iran.

Ranganna, S. (2001) Analysis and quality control for fruits and vegetable products. Tata McGrawhill Publication, New Delhi.

Reeuwijk, L. P. (2002) Procedures For Soil Analysis. Inter. Soil Ref. and Info.Center. Food and Agric. Organization of the United Nations

Sahelemedhin, S. and B. Taye (Editors) (2000) Procedures for Soil and Plant Analysis. National Soil Res. Center, Addis Ababa, Ethiopia.

Singh, J.P. (1988) A rapid method for fertermination of nitrate in soil and plant extracts. Plant and Soil, 110, 137-139.

Snoeijers, S. S., Perez-Garcia, A. Joosten, M. H. A. J. and De Wit, P. J. G. M. (2000)The effect of nitrogen on disease development and gene expression in bacterial and fungal plant pathogens. Eur. J. Plant Pathol. 106, 493-506.

Usten, N. H., Yokas, A. L. and Saygili, H. (2006) Influence of potassium and calcium level on severity of tomato pith necrosis and yield of greenhouse tomatoes. ISHS Acta. Hortic., 808,345-350.

Von Wirén, V., Gazzarrini, N., Gojon, A. and Frommer,W. B. (2000) The molecular physiology of ammonium uptake and retrieval. Current Opinion in Plant Biology, 3, 254-261.

Wu, M. C. (2002) Food Analysis and Sensory Evaluation (in Chinese). China Agric. Press, Beijing.

(Received:4 /1/2016) accepted:27/3/2016) 
تاثير مصادر مختلفة من النيتروجين مع مصادر مختلفة من الكالسيوم علي جودة الطماطم

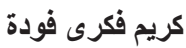

قسـم الأراضى - كلية الزراعة - جامعة المنصورة - مصر.

اجريت تجربه حقليه بمزرعه كليه الزر اعه - جامعه المنصوره خلال عام 2013 لدراسه تأثير صور مختلفه من التسميد

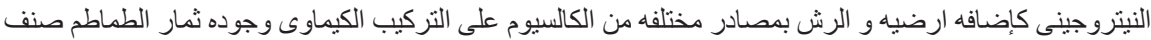

كارمن.

اشتملت التجربه على 12 معامله فى تصميم قطاعات منشقه فى 3 مكرر ات تمثل التفاعلات الممكنه بين 3 صور مختلفه

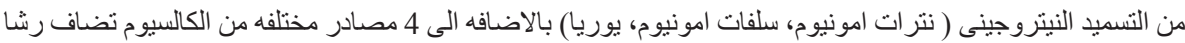

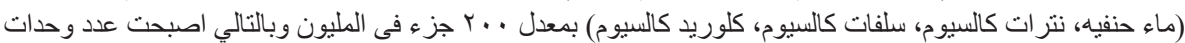

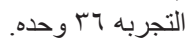

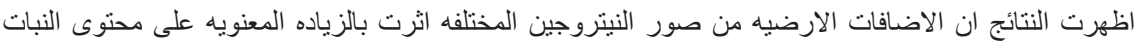

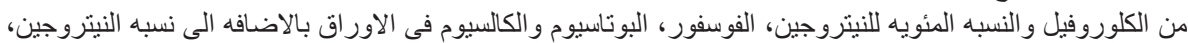

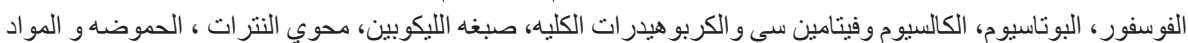

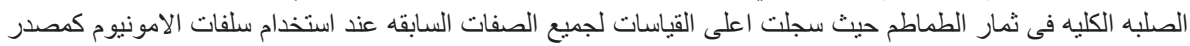

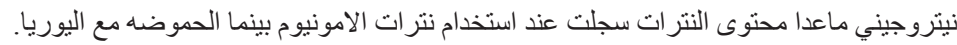

